\title{
ANALISA PENGARUH INTELLECTUAL CAPITAL TERHADAP PROFITABILITAS DAN PRODUKTIVITAS PADA SEKTOR PERBANKAN SYARIAH INDONESIA CABANG KOTA TANGERANG
}

\author{
Sendy Zul Friandi ${ }^{1}$ \\ Imam Nugroho Akbar ${ }^{2}$ \\ Dosen STMIK Raharja ${ }^{1}$, STIMK Raharja Jurusan Teknik Informatika ${ }^{2}$ \\ Jl. Jendral Sudirman No. 40, Modern Cikokol, Tangerang \\ Email : sendy@raharja.infol) imam.nugroho@ raharja.info $^{2)}$
}

\begin{abstract}
ABSTRAK
Penelitian ini bertujuan untuk mengetahui pengaruh intellectual capital terhadap profitabilitas dan produktivitas sektor perbankan syariah diindonesia. Data yang diperoleh sebanyak 10 perbankan syariah kota tangerang dengan periode 2015-2017 dan dihubungkan dengan 3 variabel penelitian, yaitu : 1 variabel independen : intellectual capitaldan 2 variabel dependen : profitabilitas dan produktivitas. Metode analisis data yang digunakan adalah uji normalitas, uji multikolinearitas, uji heteroskedastisitas, uji autokorelasi, uji determinasi, uji $t$, dan uji $F$. Hasil penelitian menunjukkan bahwa: (1) variabel VAHU, VACA, dan STVA tidak berpengaruh terhadap profitabilitas (ROA), (2) variabelVAIC berpengaruh terhadap profitabilitas (ROA), (3) variabel VACA, VAHU, STVA dan VAIC berpengaruh signifikian terhadap produktivitas (ATO).
\end{abstract}

Kata Kunci : VACA, VAHU, STVA, VAIC, profitabilitas, produktivitas..

\begin{abstract}
This study aims to determine theinfluence of intellectual capital to profitability and productivity on islamic banking in indonesia. Data obtained as many as 10 islamic banking City of Tangerang with the period from 2015 to 2017 and linked to the 3 variables of the study, namely: 1 independent variables: intellectual capital and 2 dependent variables: profitability and productivity. Data analysis methods used are test for normality, multicollinearity test, heteroskedastisitas test, autocorrelation test, a test of determination, $t$ test and $F$ test. The results showed that: (1) variable VACA,VAHU, STVA does not affect the profitability (ROA), (2) variable VAIC simultaneosly affects significant impact on profitability (ROA), and (3) variable VACA, VAHU, STVA and VAIC simultaneosly affects significant impact on productivity (ATO).
\end{abstract}

Keywords: Vaca,Vahu, Stva, Vaic, Profitability And Productivity 


\section{PENDAHULUAN \\ Latar Belakang}

Era globalisasi semakin bergulir membuat persaingan bisnis semakin kompetetif, sehingga harus memaksa perusahaan untuk meningkatkan inovasi terhadap penentuan strategi bersaing dan pengeloloaan bisnis. Para pelaku bisnis semakin menyadari bahwa kemampuan bersaing tidak hanya ditentukan oleh kepemilikan aktiva berwujud, dan ketersediaan tenaga kerja (tangible asset), tetapi lebih pada inovasi, sistem informasi, pengelolaan organisasi, dan kualitas sumber daya manusia yang dimilikinya (intangible asset) (Sholikhah,2010), Sektor perbankan dipilih karena menurut Firre dan William 2003 industri perbankan merupakan salah satu knowledge-intensive industry.

Secara umum perkembangan pertumbuhan Bank Syariah mengalami peningkatan yang cukup signifikan bemula dari periode 1992 sampai dengan 1998, hanya terdapat satu Bank Umum Syariah yaitu Bank Muamalat Indonesia dan 78 Bank Pengkreditan Rakyat (BPRS) yang telah beroperasi. Undang-undang nomor 10 tahun 1998 tentang perubahan nomor 7 tahun 1002 yang memperbolehkan setiap bank konvesional membuka sistem pelayanan syariah di cabangnya ( dual Banking System).

Intellectual Capital IC adalah kajian penelitian baru yang mendapatkan perhatian cukup besar dari para ahli diberbagai disiplin seiring dengan pertumbuhan ekonomi yang berbasis pengetahuan ( knowlage based economy) ( Stahle et al 2011;541 ). Intellectual Capital yang dimiliki perbankan syariah di Indonesia akan menciptkan nilai tambah yang dapat meningkatkan kinerja keuangan. Peningkatan kinerja keuangan merupakan sebuah sinyal positif bagi investor sehingga investor tertarik berinvestasi di perusahaan tersebut.

\section{Batasan Masalah}

Beberapa riset di berbagai Negara termasuk Indonesia membuktikan adanya hubungan antara Intellectual capital dengan kinerja keuangan dalam kontens perbankan syariah di Indonesia, Dalam penelitian ini menggunakan ROA sebagai proksi untuk menghitung profitabilitas dan ATO.Dan bagaimana pengaruhnya dengan intellectual capital pada sektor perbankan syariah. Sektor perbankan syariah Cabang kota tangerang dipilih sebagai sempel data untuk penelitian ini karena dianggap sebagai salah satu industri berbasis pengetahuan dan penelitian, Berdasarkan uraian diatas, masalah penelitian ini selanjutnya dapat dirumuskan sebagai berikut:

1. Islamic Bank Value Added Capital Employed (IB-VACA) berpengaruh terhadap profitabilitas pada perbankan syariah di Indonesia.

2. Islamic Bank Value Added Human Capital (IB-VAHU) berpengaruh terhadap profitabilitas pada perbankan syariah di Indonesia

3. Islamic Bank structural capital Value Added (IB-STVA) berpengaruh terhadap profitabilitas pada perbankan syariah di Indonesia

4. Islamisc Bank value Added Intellectual capital (IB-VAIC)berpengaruh terhadap produktivitas pada perbankan syariah di Indonesia 


\section{Hipotesis}

Hipotesis alternatif yang diajukan adalah Sebagai Berikut :

"Didugaintellectual capital pada sektor perbankan syariah,secara simultan berpengaruh secara positif dan signifikan terhadap profitabilitas dan produktivitas ekonomi syariah kota tangerang"

\section{Kerangka Pemikiran}

Dalam memberikan gambaran mengenai pokok pikiran pada penelitian secara skematis kerangka pemikiran penelitian sebagai berikut :

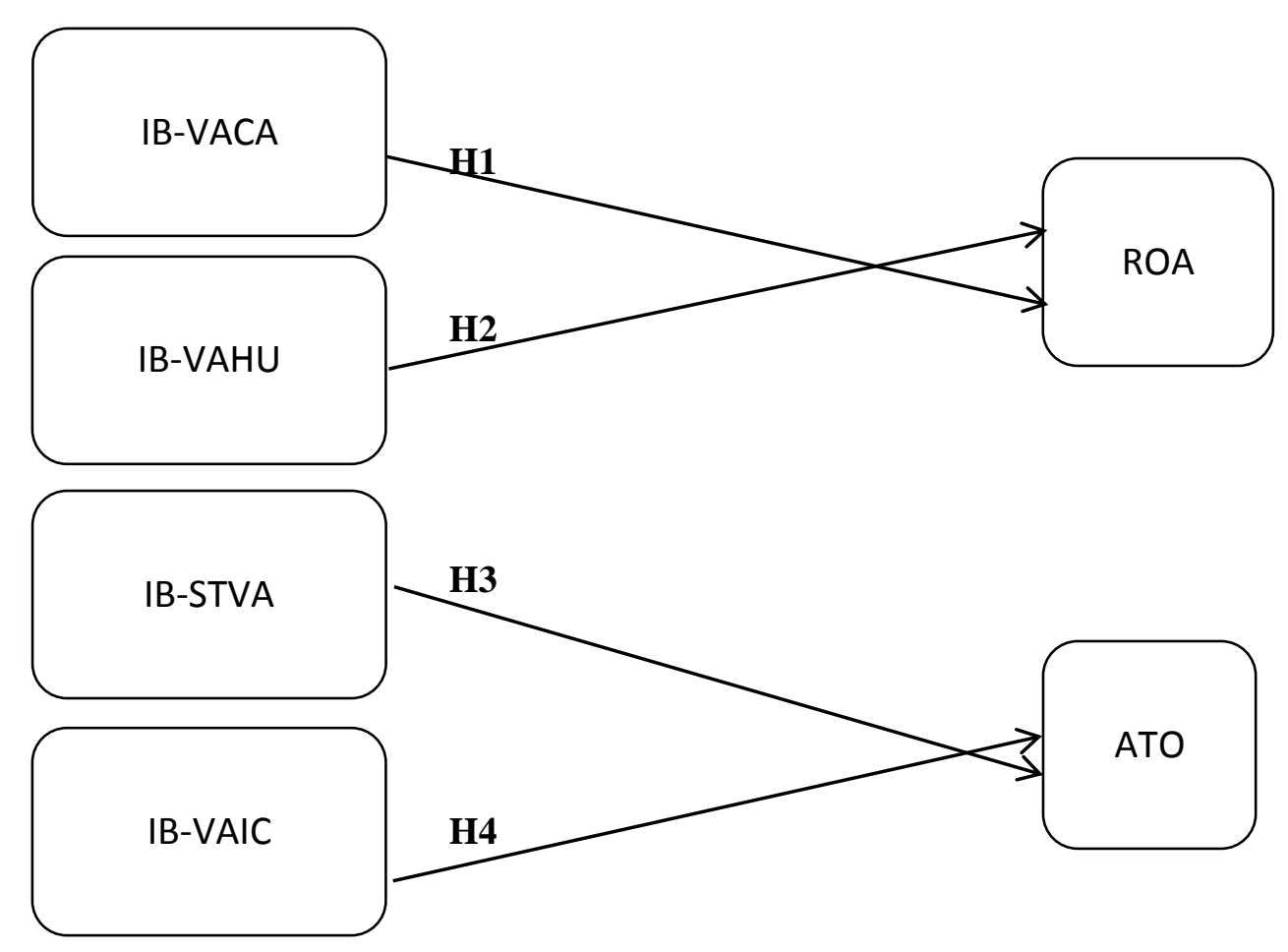

Gambar 1. Cart Skema Kerangka Pemikiran

$\mathrm{H}_{1}$ : Value Added Capital Employed perbankan syariah (IB-VACA) berpengaruh signifikan terhadap ROA

H2: Value Added Human Capital perbankan syariah (IB-VAHU) berpengaruh signifikan terhadap ROA

H3: Structural Capital Value Added perbankan syariah (IB-STVA) berpengaruh terhadap ATO

H4: Value Added Intellectual Capital perbankan syariah (IB-VAIC) berpengaruh terhadap ATO 


\section{LITERATUR REVIEW}

Literature Reviewini dilakukan oleh peneliti untuk mengetahui landasan awal dan sebagai pendukung bagi kegiatan penelitian yang dilakukan oleh peneliti, sehingga dapat menghindari pengulangan hal yang sama dalam penelitian dan dapat melakukan pengembangan ketingkat yang lebih tinggi dalam rangka menyempurnakan atau melengkapi penelitian yang nantinya di kembangkan lagi kedepannya.

Adapun Literature Review sebagai berikut :

1. Peneletian yang dilakukan oleh Hanif Hasan J. dkk. Yaitu. Analisis Investasi Saham Subsektor Properti dan Real Estate di Indonesia

2. Peneletian yang dilakukan oleh Siti Rafika Putri. Yaitu Pengaruh perilaku WPS dalam Pencarian Pengobatan PMS, Lingkungan dan Status Kesehatan Terhadap Kualitas Hidup WPS di Kelurahan Dadap Tangerang

3. Peneletian yang dilakukan oleh Rini Kundaryati. Dkk. Yaitu hubungan Antara pendidikan dan Sumber Informasi Dengan Tingkat Pengetahuan ibu Tentang Post Partum Blues di RB Ratna Komala Bekasi Jawa Barat.

4. Penelitian yang dilakukan Ifran Sanni Dkk. Yaitu Analisa pengaruh kemampuan kerja pegawai dan komunikasi antar pribadi terhadap kualitas pelayanan perusahaan PT, Indosat

\section{MERODELOGI PENELITIAN}

Analisis data yang digunakan adalah analisis regresi dengan tujuan mengetahui adanya pengaruh antar variabel independen dan variabel dependen serta menguji hipotesis yang diajukan..Adapun rumusan yang digunakan dalam penelitian ini adalah sebagai berikut :

\section{Analisis Statistik Deskriptif}

Analisis statistic deskripstif dalam penelitian ini digunakan untuk memberikan deskripsi mengenai variabel-variabel penelitian yaitu: VACA, VAHU, STVA, ROA dan ATO. Penelitian menggunakan tabel ini akan menghasilkan nilai rata-rata (mean), standar deviasi, varian, nila maximum, nilai minimum, sum dan interval (range).

\section{Uji Hipotesis}

Uji hipotesis dnegan model regresi linier berganda ( mulutiple linier regretion) digunakan dalam penelitian ini, karena jumlah variabel independen $(\mathrm{X})$ lebih dari satu dan bersifat kuantitatif (metric), sedangkan jumlah variabel dependen (Y) terdiri dari satu variebel dan juga bersifat kuantitatif(metric). Tahapan untuk menguji hipotesis dalam penelitian ini adalah sebagai berikut: 


\section{a). Uji Statistik F (Uji Signifikan Simultan)}

Uji simultan dengan F-test ini bertujuan untuk mengetahui pengaruh bersama sama variabel independen terhadap variabel dependen. Hasil F-test ini berpengaruh secara bersama-sama variabel independen terhadap variable dependen.Jika nilai signifikansi F (P-value) pada kolom sig lebih kecil dari level of significant yang ditentukan, atau hitung (padakolom F) lebih besar dari F table. Dimana F tabel dihitung dengan cara : $\mathrm{dfl}=\mathrm{k}-1$, dan df $2=\mathrm{n}-\mathrm{k}$, dimana $\mathrm{K}$ adalah jumlah variabel dependen, dan independen (Ghozali,2011).

\section{b). Uji Statistik T}

Uji statistik $\mathrm{T}$ menunjukkan seberapa jauh pengaruh satu variabel independen secara individual dalam menerangkan variabel dependen (Ghozali, 2011). Dalam pengujian ini, penerimaan dan penolakan hipotesis dilakukan dengan beberapa kriteria berikut: $\mathrm{H}_{0}$ diterima : jika t dihitung $<\mathrm{t}$ tabel $($ sig $>0,05)$

Hal ini menunjukkan koefisien regresi tidak signifikan dan secara parsial variabel independen tersebut berpengaruh signifikan terhadap variabel dependen.

\section{c). Uji Analisis Regresi Linier Berganda}

Untuk menguji signifikan dari suatu hipotesis perlu menggunakan koefesien determinasi, uji T , uji F.Alat analisis yang digunaan dalam penelitian ini adalah regresi berganda ( multi regretion ). Secara umum model regresi ini dapat ditulis sebagai berikut.

$$
\mathbf{Y}_{(1,2)}=\mathbf{a}+\mathbf{b}_{1} \mathbf{X}_{1}+\mathbf{b}_{2} \mathbf{X}_{2+} \mathbf{b}_{3} \mathbf{X}_{3}+\mathbf{e}
$$

Dimana :

$$
\begin{aligned}
& \mathrm{Y}_{1}=\text { ROA } \\
& \mathrm{Y}_{2}=\mathrm{ATO} \\
& \mathrm{X}_{1}=\mathrm{iB}-\mathrm{VACA} \\
& \mathrm{X}_{2}=\mathrm{iB}-\mathrm{VAHU} \\
& \mathrm{X}_{3}=\mathrm{iB}-\mathrm{STVA} \\
& \mathrm{a}=\text { Konstanta persamaan regresi } \\
& \mathrm{b}=\text { nilai koefesien regresi ( intellectual capital }) \\
& \mathrm{e}=\text { variabel lain yang tidak bisa dijelaskan dalam fungsi }
\end{aligned}
$$

\section{d). Koefisien Determinasi $\left(\mathbf{R}^{2}\right)$}

Koefisien determinasi $\left(\mathrm{R}^{2}\right)$ digunakan untuk mengukur seberapa jauh kemampuan model dalam menerangkan variasi variabel dependen.Nilai $\mathrm{R}^{2}$ antara nol dan satu.Nilai $\mathrm{R}^{2}$ yang kecil menunjukkan bahwa kemampuan variabel-variabel independen dalam menjelaskan variasi-variasi dependen sangat terbatas. Nilai yang mendekati satu berarti variabel-variabel independen hampir semua informasi yang dibutuhkan untuk memprediksi variasi variabel dpenden (Ghozali,2011). 


\section{OBJEK PENELITIAN}

Data yang digunakan dalam penelitian ini adalah laporan keuangan perusahaan perbankan syariah yang ada di Indonesia khususnya kota yang terdafta di Otoritas Jasa Keuangan (OJK) selama periode 2015 hingga 2017. Data ini diperoleh dari www.ojk.go.id dan situs resmi masing-masing perusahaan. Populasi perbankan syariah yang ada di Indonesia selama periode 2015 hingga 2017 berjumlah 36 bank. Berdasarkan kriteria yang ditetapkan di bab sebelumnya maka diperoleh jumlah sampel sebanyak 10 perusahaan. Peneliti mengambil sampel sesuai dengan kriteria yang ditentukan. Prosedur pemiihan sampel dapat dilihat pada tebel berikut:

Tabel 1

Kriteria Pemilihan Sampel

\begin{tabular}{|c|l|c|}
\hline No & \multicolumn{1}{|c|}{ Keterangan } & Jumlah \\
\hline 1. & $\begin{array}{l}\text { Jumlah Bank syariah di Indonesia yang terdaftar di } \\
\text { Otoritas Jasa Keuangan selama periode 2012-2015 }\end{array}$ & 36 \\
\hline 2. & $\begin{array}{l}\text { Jumlah Unit Usaha Syariah yang tidak termasuk dalam } \\
\text { sampel penelitian }\end{array}$ & $(25)$ \\
\hline 3. & $\begin{array}{l}\text { Bank syariah yang mengalami kerugian 2 tahun berturut } \\
\text { turut }\end{array}$ & $\mathbf{1 0}$ \\
\hline & Data perusahaan yang diolah & \\
\hline
\end{tabular}

Sumber: Data sekunder yang diolah 2017

\section{HASIL PENGUJIAN DAN PEMBAHASAN}

\section{Statistik Deskriptif}

Statistik deskriptif menggambarkan tentang ringkasan data-data penelitian seperti nilai minimum, maksimum, mean, standard deviasi dari masing- masing variabel yang terdapat dalam penelitian. Perusahaan yang memenuhi kriteria dari penelitian ini sebanyak 40 sampel :

Tabel 2

Descriptive Statistics

\begin{tabular}{|l|r|r|r|r|r|}
\hline & $\mathrm{N}$ & Minimum & Maximum & \multicolumn{1}{c|}{ Mean } & $\begin{array}{c}\text { Std. } \\
\text { Deviation }\end{array}$ \\
\hline (iB-VACA) & 40 &, 092 &, 924 &, 32573 &, 187814 \\
(iB-VAHU) & 40 &, 932 & 4,656 & 1,90783 &, 864682 \\
(iB-STVA) & 40 &,- 073 &, 785 &, 38612 &, 224030 \\
ROA & 40 &, 015 & 2,284 &, 91995 &, 636597 \\
ATO & 40 &, 523 & 9,825 & 5,09228 & 1,735963 \\
Valid N & 40 & & & & \\
(listwise) & & & & & \\
\hline
\end{tabular}

Sumber: data hasil pengolahan SPSS 
Dari output statistik deskriptif pada tabel 4.2 diatas maka dapat dilihat bahwa:

1) $\mathrm{N}=40$ berarti jumlah data yang diolah dalam penelitian ini adalah 40 sampel yang terdiri dari 10 perusahaan selama 4 tahun.

2) nilai terendah untuk Islamic BankValue Added Capital Employed (IB-VACA) sebesar 0,092 adalah bank BCA syariah pada tahun 2015, nilai tertinggi sebesar 0,924 adalah bank Mega Syariah pada tahun 2012. Rata- rata IB-VACA sebesar 0,32573 pada standar deviasi 0,187814. Artinya, dari data variabel IB-VACA memusat atau pada umumnya terletak pada 0,32573 . Nilai rata-rata lebih besar dari standar deviasi yaitu $0,32573>0,187814$, bearti bahwa sebaran nilai IB-VACA baik.

3) Nilai terendah untuk Islamic BankValue Added Human Capital (IB-VAHU) sebesar 0,932 adalah bank Bukopin Syariah pada tahun 2013 . nilai tertinggi sebesar 4,656 adalah bank May Bank Syariah pada tahun 2015. Rata- rata IB-VAHU sebesar 1,90783 pada standar deviasi 0,864682. Artinya, dari data variabel IB-VAHU memusat atau pada umumnya terletak pada 1,90783. Nilai rata-rata lebih besar dari standar deviasi yaitu 1,90783>0,864682, berarti bahwa sebaran nilai IB-VAHU baik.

4) Nilai terendah untuk Islamic BankStructural Capital Value Added (IB-STVA) sebesar $-0,073$ adalah bank Bukopin syariah pada tahun 2013. nilai tertinggi sebesar 0,785 adalah bank May bank syariah pada tahun 2015. Rata- rata IB-STVA sebesar 0,38612 pada standar deviasi 0,224030. Artinya, dari data variabel IB-STVA memusat atau pada umumnya terletak pada 0,38612. Nilai rata-rata lebih besar dari standar deviasi yaitu 0,38612>0,224030, berarti bahwa sebaran nilai IB-STVA baik.

5) Nilai terendah untuk Return On Asset (ROA) sebesar 0,015 adalah bank BRI syariah pada tahun 2014. nilai tertinggi sebesar 2,284 adalah bank May Bank syariah pada tahun 2014. Rata- rata ROA sebesar 0,91995 pada standar deviasi 0,636597. Artinya, dari data variabel ROA memusat atau pada umumnya terletak pada 0,91995. Nilai rata-rata lebih besar dari standar deviasi yaitu 0,91995> 0,636597, berarti bahwa sebaran nilai ROA baik.

Nilai terendah untuk Asset Turn Over(ATO) sebesar 0,523 adalah bank jabar banten syariah pada tahun 2014. nilai tertinggi sebesar 9,825 adalah bank May Bank Syariah pada tahun 2015. Rata- rata ATO sebesar 5,09228 pada standar deviasi 1,735963. Artinya, dari data variabel ATO memusat atau pada umumnya terletak pada 5,09228. Nilai rata-rata lebih besar dari standar deviasi yaitu 5,09228>1,735963, berarti bahwa sebaran nilai ATO baik..

\section{Uji Asumsi Klasik}

Pengujian dengan grafik distribusi dilakukan dengan melihat grafik histogram yang membandingkan antara data obserasi dengan distribusi yang mendekati distribusi normal. Jika distribusi data residual normal, maka garis yang digambarkan data yang sesungguhnya akan mengikuti garis diagonalnya. Berikut ini adalah hasil Uji Normalitas : 


\section{Hasil Uji Normalitas}

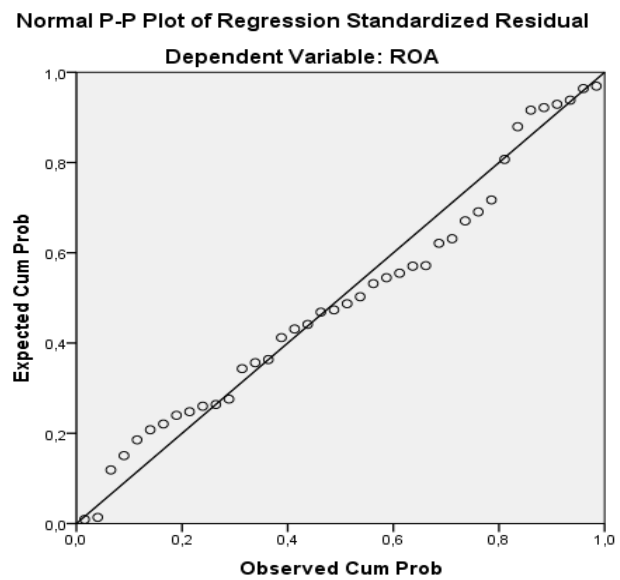

Gambar 2

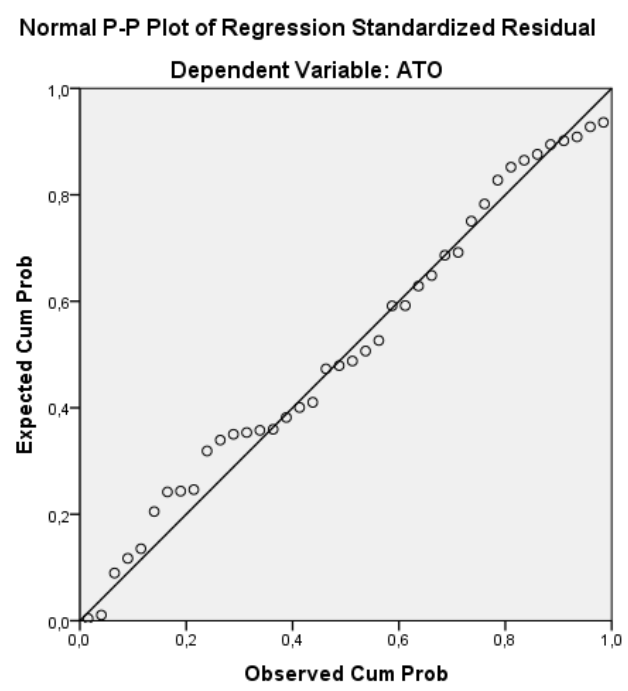

Gambar 3

Sumber : Lampiran Hasil olah data Uji Normalitas

Berdasarkan hasil uji normalitas diatas menunjukan bahwa pada Grafik normal P-Plot membentuk satu garis lurus diagonal yang ploting data residualnya mengikuti garis diagonalnya, maka dapat disimpulkan bahwa data yang diuji berdistribusi Normal.

\section{Uji Multikolineritas}

Uji Multikolineritas bertujuan untuk menguji apakah model regresi ditemukan adanya kolerasi antar variabel bebas (independen). Metode untuk menguji ada tidaknya multikolonieritas dapat dilihat dari Tolerance Value (TOL) atau Variance Inflation Factor (VIF). 
Tabel 3

Hasil Uji Multikolinearitas dengan Metode VIF

Coefficients $^{\mathrm{a}}$

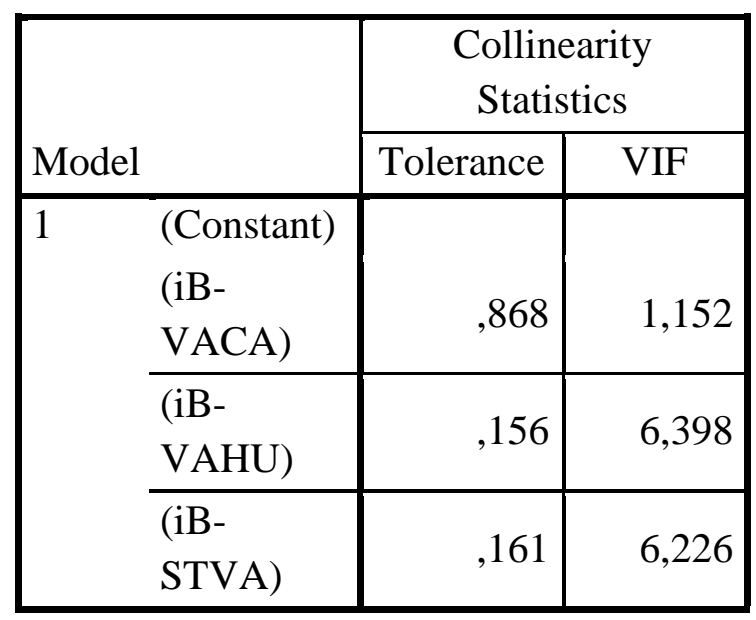

a. Dependent Variable: ROA,ATO

Sumber : Lampiran Hasil olah data Uji Multikolinearitas

Dari hasil pengujian dan tabel 4.3, terlihat bahwa:

1) Variabel independen VACA tidak ditemukan masalah multikolonearitas karena angka tolerance sebesar 0,868 dan angka VIF sebesar 1,152 atau $1,152<10$.

2) Variabel independen VAHU tidak ditemukan masalah multikolonearitas karena angka tolerance sebesar 0,156 dan angka VIF sebesar 6,398 atau $6,398<10$.

Variabel independen STVA tidak ditemukan masalah multikolonearitas karena angka tolerance sebesar 0,161 dan angka VIF sebesar 6,226 atau 6,226 < 10 .

\section{Uji Heteroskedastisitas}

Uji heteroskedastisitas dilakukan dengan menggunakan uji Glesjer untuk mendeteksi adanya adanya heteroskedastisitas dari tingkat signifikansi.Jika tingkat signifikansi berada diatas $5 \%$ berarti tidak terjadi heteroskedastisitas dan bila berda di bawah $5 \%$ berarti terjadi gejala heteroskedastisitas. 
Hasil Uji Heterokedastisitas dengan grafik scatterplot

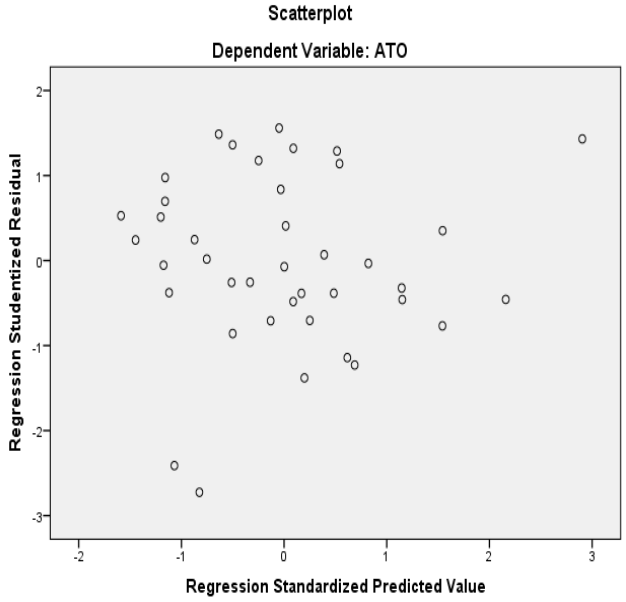

Gambar 4

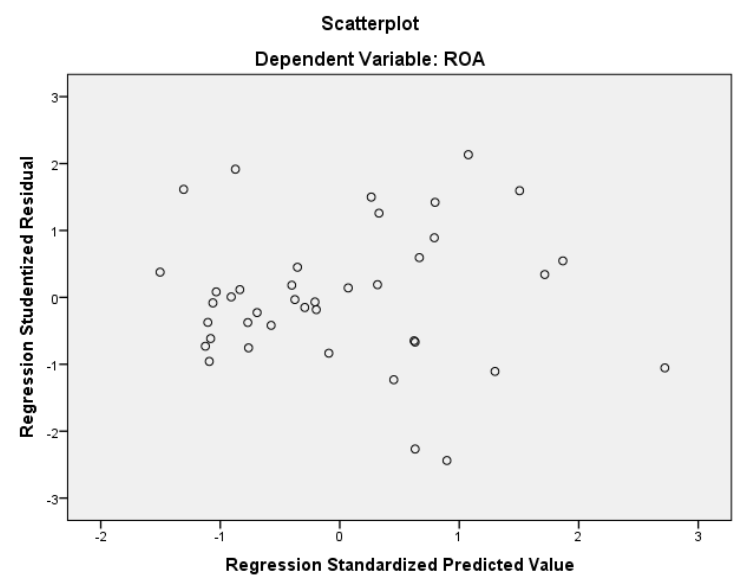

Gambar 5

Berdasarkan hasil uji heterokedastisitas dengan menggunakan grafik scatterplot terlihat bahwa tidak ada pola yang jelas, serta titik-titik menyebar diatas dan dibawah angka 0 pada sumbu Y. Oleh karena itu, dapat disimpulkan bahwa tidak terjadi heterokedastisitas pada model regresi ini.

\section{Uji Hipotesis (Intelectual Capital terhadap ROA)} Simultan ANOVA ( Uji F)

Tabel 6

Hasil ANOVA Regresi linier Berganda

ANOVA $^{\mathrm{a}}$

\begin{tabular}{|c|c|c|c|c|c|}
\hline Model & $\begin{array}{l}\text { Sum of } \\
\text { Squares }\end{array}$ & Df & Mean Square & $\mathrm{F}$ & Sig. \\
\hline $\begin{array}{ll}1 & \text { Regression }\end{array}$ & 6,974 & 3 & 2,325 & 9,477 &, $000^{b}$ \\
\hline Residual & 8,831 & 36 & ,245 & & \\
\hline Total & 15,805 & 39 & & & \\
\hline
\end{tabular}


a. Dependent Variable: ROA

b. Predictors: (Constant), (iB-STVA), (iB-VACA), (iB-VAHU)

Sumber : Lampiran Hasil Analisis Regresi Berganda,2017

Dari pengujian regresi pada tabel 4.6 diperoleh $\mathrm{F}$ hitung 9,477 dengan probabilitas sebesar 0,000. Karena probabilitas lebih kecil dari 0,05 sehingga dapat disimpulkan H0 ditolak dan Ha diterima. Dapat diartikan bahwa VACA, VAHU,STVA secara bersama-sama (simultan) berpengaruh signifikan positif terhadap ROA.

\section{Uji Parameter Induvidual (uji t)}

Tabel 7

Hasil Analisis Regresi ROA

Coefficients $^{\mathrm{a}}$

\begin{tabular}{|c|c|c|c|c|c|}
\hline \multirow[b]{2}{*}{ Model } & \multicolumn{2}{|c|}{$\begin{array}{l}\text { Unstandardized } \\
\text { Coefficients }\end{array}$} & \multirow{2}{*}{\begin{tabular}{|c|}
$\begin{array}{c}\text { Standardized } \\
\text { Coefficients }\end{array}$ \\
Beta
\end{tabular}} & \multirow[b]{2}{*}{$\mathrm{T}$} & \multirow[b]{2}{*}{ Sig. } \\
\hline & B & Std. Error & & & \\
\hline (Constant) &,- 252 & ,279 & &,- 902 & ,373 \\
\hline (iB-VACA) &, 821 & ,453 &, 242 & 1,812 & ,078 \\
\hline (iB-VAHU) & ,426 & ,232 & ,579 & 1,836 & ,075 \\
\hline (iB-STVA) & ,237 & ,883 & ,083 & ,268 & ,790 \\
\hline
\end{tabular}

a. Dependent Variable: ROA

Sumber : Lampiran Hasil Analisis Regresi , 2017

Secara matematis hasil regresi linear berganda tersebut dapat dituliskan sebagai berikut :

$$
\mathrm{ROA}=-0,252+0.821 \mathrm{iB}-\mathrm{VACA}+0,426 \mathrm{iB}-\mathrm{VAHU}+0.237 \mathrm{iB}-\mathrm{STVA}
$$

Untuk menguji hasil yang didapat dari persamaan regresi linier maka dilakukan uji t. jika statistik $\mathrm{T}$ hitung < T tabel maka Ho diterima, dap dan jika statistik T hitung $>$ Ttabel maka Ho ditolak. Berdasarkan hasil perhitungan di atas maka diperoleh :

1. Koefisien IB-VACA memiliki nilai $\mathrm{t}$ hitung sebesar $1,812<2,005 \mathrm{t}$ tabel dengan signifikansi sebesar 0,078 berarti lebih besar dari 0,05, maka Ho diterima dengan kata lain IB-VACA $\left(\mathrm{X}_{1}\right)$ berpengaruh positif dan tidak signifikan terhadap Profitabilitas (ROA)

2. Koefesien IB-VAHU memiliki nilai $\mathrm{t}$ hitung sebesar $1,836<2,005 \mathrm{t}$ tabel dengan signifikansi sebesar 0,075 berarti lebih besar dari 0,05, maka Ho diterima dengan kata lain IB-VAHU $\left(\mathrm{X}_{2}\right)$ berpengaruh positif dan tidak signifikan terhadap profitabilitas (Y)

3. Koefisien IB-STVA memiliki nilai $\mathrm{t}$ hitung sebesar $0.268<2,005 \mathrm{t}$ tabel dengan signifikansi sebesar 0,790 berarti lebih besar dari 0,005 maka Ho 
dterima dengan kata lain IB-STVA $\left(\mathrm{X}_{3}\right)$ berpengaruh negatif dan tidak signifikan terhadap profitabilitas.

\section{Pengujian Hipotesis (Intelectual Capital terhadap ATO) Simultan ANOVA (Uji F)}

Tabel 8

\section{Hasil ANOVA Regresi linier Berganda}

ANOVA $^{\mathrm{a}}$

\begin{tabular}{|l|l|l|l|l|l|}
\hline Model & $\begin{array}{l}\text { Sum } \\
\text { Squares }\end{array}$ & df & Mean Square & F & Sig. \\
\hline Regression & 50,574 & 3 & 16,858 & 9,064 &, $000^{\mathrm{b}}$ \\
Residual & 66,956 & 36 & 1,860 & & \\
Total & 117,529 & 39 & & & \\
\hline
\end{tabular}

a. Dependent Variable: ATO

b. Predictors: (Constant), (iB-STVA), (iB-VACA), (iB-VAHU)

Sumber : Lampiran Hasil Analisis Regresi Berganda,2017

Dari pengujian regresi pada tabel 4.6 diperoleh $\mathrm{F}$ hitung 9,477 dengan probabilitas sebesar 0,000. Karena probabilitas lebih kecil dari 0,05 sehingga dapat disimpulkan H0 ditolak dan Ha diterima. Dapat diartikan bahwa VACA, VAHU,STVA secara bersama-sama (simultan) berpengaruh signifikan positif terhadap ATO.

\section{Uji Parameter Induvidual (uji t)}

uji $\mathrm{T}$ (T-test) bertujuan untuk menunjukkan seberapa jauh pengaruh satu variabel independen dean variabel kontrol secara individual dalam menerangkan variasi variabel dependen yang di masukkan dalam model signifikan 5\%

Tabel 9

\section{Hasil Analisis Regresi ATO}

\section{Coefficients $^{\mathrm{a}}$}

\begin{tabular}{|c|c|c|c|c|c|c|}
\hline \multirow{2}{*}{\multicolumn{2}{|c|}{ Model }} & \multicolumn{2}{|c|}{ Unstandardized Coefficients } & \multirow{2}{*}{$\begin{array}{c}\begin{array}{c}\text { Standardized } \\
\text { Coefficients }\end{array} \\
\text { Beta }\end{array}$} & \multirow[b]{2}{*}{$\mathrm{t}$} & \multirow[b]{2}{*}{ Sig. } \\
\hline & & $\mathrm{B}$ & Std. Error & & & \\
\hline \multirow[t]{4}{*}{1} & (Constant) & 1,254 & ,769 & & 1,631 &, 112 \\
\hline & (iB-VACA) & 5,059 & 1,248 &, 547 & 4,054 & 000 \\
\hline & (iB-VAHU) & 2,254 & ,639 & 1,123 & 3,528 & ,001 \\
\hline & (iB-STVA) & $-5,462$ & 2,432 &,- 705 & $-2,246$ & 031 \\
\hline
\end{tabular}

a. Dependent Variable: ATO

Sumber : Lampiran Hasil Analisis Regresi , 2017 
Secara matematis hasil regresi linear berganda tersebut dapat dituliskan sebagai berikut :

ATO $=1,254+5,059$ iB-VACA + 2,254 iB-VAHU - 5,462 iB-STVA

Untuk menguji hasil yang didapat dari persamaan regresi linier maka dilakukan uji t. jika statistik $\mathrm{T}$ hitung < $\mathrm{T}$ tabel maka Ho diterima, dap dan jika statistik $\mathrm{T}$ hitung > Ttabel maka Ho ditolak. Berdasarkan hasil perhitungan di atas maka diperoleh :

1) koefisien IB-VACA memiliki nilai t hitung sebesar 4,054>2,005 t tabel dengan signifikansi sebesar 0,000 berarti lebih kecil dari 0,05, maka Ho ditolak, dengan kata lain IB-VACA $\left(\mathrm{X}_{1}\right)$ berpengaruh positif dan signifikan terhadap Produktivitas (ATO)

2) koefesien IB-VAHU memiliki nilai t hitung sebesar 3,528>2,005 t tabel dengan signifikansi sebesar 0,001 berarti lebih kecil dari 0,05, maka Ho ditolak dengan kata lain IB-VAHU $\left(\mathrm{X}_{2}\right)$ berpengaruh positive dan signifikan terhadap produktivitas (ATO)

koefisien IB-STVA memiliki nilai $\mathrm{t}$ hitung sebesar $-2,246<2,005 \mathrm{t}$ tabel dengan signifikansi sebesar 0,031 berarti lebih besar dari 0,05 maka Ho ditolak dengan kata lain IB-STVA $\left(\mathrm{X}_{3}\right)$ berpengaruh negative dan signifikan terhadap produktivitas (ATO).

\section{HASIL PEMBAHASAN UMUM}

Pengaruh Value Added Capital Employed perbankan syariah (IB-VACA) terhadap ROA (Return On Asset) : Koefisien Value Added Capital Employed adalah positif sebesar 0,821menunjukan bahwa apabila Risk Based Capital meningkat sebesar 1 satuan maka Return On Asset akan meningkat sebesar 0,821. Nilai Probabilitas (p-value) sebesar 0,078, hal ini lebih besar dari taraf signifikansi 0,05 ,artinya bahwa $i b$-VACA tidak berpengaruh signifikan terhadap Return On Asset.Penelitian ini didukung oleh penelitian suhendah (2017) yang menemukan bahwa physical capital tidak berpengaruh signifikan terhadap profitabilitas.Hal ini memberikan indikasi bahwa asset fisik yang terdapat pada perbankan syariah bukan merupakan aset utama yang dapat meningkatkan profitabilitas .Hal itu sesuai dengan sekarang ini dimana pesatnya perkembangan teknologi informasi yang merupakan asset ingtangible yang belum mampu diukur dan dilaporkan dengan tepat pada laporan keuangan perbankan syariah. Dengan demikian hipotesis pertama yang menyatakan "Value Added Capital Employed perbankan syariah (IB-VACA) berpengaruh signifikan terhadap ROA" (DITOLAK).

Pengaruh Value Added Human Capital perbankan syariah (IB-VAHU) terhadap ROA :Koefisien Value Added Human Capital adalah positif sebesar 0,426menunjukan bahwa apabila Value Added Human Capital meningkat sebesar 1 satuan maka Return On Asset akan meningkat sebesar 0,426. Nilai Probabilitas (p-value) sebesar 0,075, hal ini lebih besar dari taraf signifikansi 0,050, artinya bahwa Value Added Human Capital tidak 
berpengaruh signifikan terhadap Return On Asset . Hasil Penelitian ini sama dengan penelitian yang dilakukan oleh suhendah (2012) yang menemukan bahwa human capital tidak berpengaruh signifikan terhaqdap profitabilitas. Hal itu didukung penelitian hermanus dan evelyn (2013) yang menunjukan bahwa vahu tidak berpengaruh signifikan terhadap profitabilitas. Hal itu dikerenakan,dari sudut pandang pelaporan keuangan gaji pegawai yang merupakan indikator VAHU digolongkan sebagai beban yang mereduksi jumlah laba perusahaan. Selain itu, bahwa human capital pada perusahaan perbankan syariah yang dilihat dari beban karyawan ini belum berkonstribusi secara maksimal terhadap perolehan ROA. Hasil penelitian ini sejalan dengan penelitian Firrer dan Williams (2003) dan bertolak belakang dengan penelitian Chen et.al (2005) dan Ting dan Lean (2009). Demikian hipotesis kedua yang menyatakan "Value Added Human Capital perbankan syariah (IB-VAHU) berpengaruh signifikan terhadap ROA" (DITOLAK).

Pengaruh Structural Capital Value Added perbankan syariah (IB-STVA) berpengaruh terhadap ATO : Koefisien Structural Capital Value Added adalah positif sebesar -5,462menunjukan bahwa apabila Structural Capital Value Added meningkat sebesar 1 satuan maka Asset Turn Over akan menurun sebesar -5,462. Nilai Probabilitas (p-value) sebesar 0,031, hal ini lebih kecil dari taraf signifikansi 0,05, artinya bahwa Structural Capital Value Added berpengaruh signifikan terhadap Asset Turn Over. Hasil ini konsisten dengan penelitian suhendah (2012) yang menemukan bahwa STVA berpengaruh signifikan terhadap ATO. Secara umum dalam empat tahun pengamatan pada penelitian ini ,perusahaan memiliki value added terbesar dari sisi physical capital dan structural capital. Artinya perusahaan perbankan syariah diindonesia mulai dapat memanfaatkan dan memaksimalkan keahlian jaringan serta pengelola modal fisik secara lebih baik untuk menciptakan produktivitas yang unggul.Dengan demikian hipotesis ketujuh yang menyatakan "Structural Capital Value Added perbankan syariah (IB-STVA) berpengaruh terhadap ATO” (DITERIMA).

Pengaruh Value Added Intellectual Capital perbankan syariah (IB-VAIC) berpengaruh terhadap ATO : Berdasarkanhasil regresi linier berganda ANOVA diperoleh nilai probabilitas ( $\mathrm{p}$-value) sebesar 0,000 lebih kecil dari nilai signifikansi 0,05. Oleh karena itu, dapat disimpulkan bahwa variabel iB-VAIC ${ }^{\mathrm{TM}}$ (iB-VACA, iB-VAHU ,iB-STVA) berpengaruh signifikan terhadap Asset Turn Over.Hasil ini konsisten dengan penelitian suhendah (2012) yang menemukan bahwa VAIC berpengaruh signifikan terhadap ATO. Hasil peneliitan ini sesuai dengan resource based theory yang menjelaskan bahwa perusahaan dapat memepertahankan produktivitas dengan keunggulan kompetitif yang dimiliki perusahaan dengan cara mengimplementasikan strategi untuk menciptakan value added..Dengan demikian hipotesis kedelapan yang menyatakan "Structural Capital Value Added perbankan syariah (IB-STVA) berpengaruh terhadap ATO” (DITERIMA). 


\section{KESIMPULAN}

1. Secara parsial $V A C A, V A H U, S T V A$ tidak berpengaruh signifikan terhadap profitabilitas (ROA) perusahaan perbankan syariah di Indonesia periode 2015-2017.

2. Secara parsial VACA, VAHU, STVA berpengaruh signifikan terhadap produktivitas (ATO) perusahaan perbankan syariah di Indonesia periode 2015-2017.

3. Secara bersama-sama VAIC berpengaruh signifikan terhadap profitabilitas (ROA) dan produktivitas (ATO) perusahaan perbankan syariah di Indonesia periode 2015-2017

4. Hasil uji koefisien determinasi menunjukkan bahwa Adjusted R Square adalah sebesar 0.395 dan 0.383 atau $39.5 \%$ dan $38.3 \%$ artinya profitabilitas dan produktivitas dapat dijelaskan oleh VACA, VAHU, STVA dan VAIC atau dengan kata lain $60.5 \%$ dan $61.7 \%$ dijelaskan atau dipengaruhi oleh variabel lain yang tidak dimasukkan dalam penelitian ini.

5.

\section{SARAN SARAN}

Bagi penelitian selanjutnya dapat dilakukan dengan menambah variabel lainsebagai variabel independen dan menambah jumlah sampel dalam penelitian agar hasil penelitian yang didapat lebih baik. Serta disarankan untuk mengukur profitabilitas perusahaan dengan menggunakan indikator profitabilitas lainnya seperti Return in Equity (ROE), Laba per Lembar Saham dan Net Profit Margin (NPM).

\section{DAFTAR PUSTAKA}

[1] Ghozali, Imam.(2011). "Aplikasi Analisis Multivariate Dengan Program SPSS". Semarang: Badan Penerbit Universitas Diponegoro

[2] Accounting Standards Board. (2016). "Goodwill and Intangible Assets, FRS 10".Accounting Standards Board, London.

[3] Solikhah , B.Rohman .(2010). Impliasi Intelectual Capital terhadap financial performance Growth ,dan MV. Studi empires dengan pendekatan simpesification .makalah ini dipresentasikan pada simposiom misiona akutansi XII di purwakarta.

[4] Dahlan Siamat. 2011. Managemen Lembaga Keuangan Kebijakan Moneter dan Perbankan.Edisi ke lima. Jakarta : Fakultas Ekonomi Universitas Indonesia

[5] Astuti, Partiwi Dwi dan Sabeni, Arifin. (2012). Hubungan Intellectual Capital dan Business Performance dengan Diamond Spesification: Sebuah Perspektif Akuntansi. SNA VII. Solo. pp. 694-707.

[6] Rahman, Harif. 2011. Pengaruh economic value added (EVA), return on asset (ROA), dan persentase kepemilkan modal saham asing terhadap harga saham pada perusahaan perbankan yang terdaftar di Bursa Efek Indonesia (BEI). Tesisdipublikasikan.Universitas Negeri Padang. 
[7] International Accounting Standards Board. (2014). "Summary of IAS 38".available online at: www.iasplus.com

[8] Faza Fardin, dan Hidayah Erna .(2014)." Pengaruh Intelectual Capital terhadap profitabilitas produktivitas dan nilai perusahaanpada perusahaan perbankan" :EKBISI Vol VII,No.2(Hal 86-199) ISSN:1907-9109.

[9] Sudarsono, Heri. (2014). Bank dan Lembaga Keuangan Syariah Deskripsi dan Ilustrasi, Ekonisia, Yogyakarta 